\author{
Institut für Tierernährung \\ der Vetsuisse-Fakultät Universität Zürich
}

Direktorin: Prof. Dr. med. vet. Annette Liesegang

Arbeit unter wissenschaftlicher Betreuung von

Prof. Dr. med. vet. Annette Liesegang

\title{
UV-light and dietary vitamin $D$ and their effects on ionized calcium and 25-OH-D plasma concentrations in captive gentoo penguins (Pygoscelis papua).
}

\author{
Inaugural-Dissertation \\ zur Erlangung der Doktorwürde der \\ Vetsuisse-Fakultät Universität Zürich
}

vorgelegt von

Ursina Tröndle

Tierärztin

von Zürich, ZH

genehmigt auf Antrag von

Prof Dr. med. vet. Annette Liesegang, Referentin 



\section{Inhaltsverzeichnis}

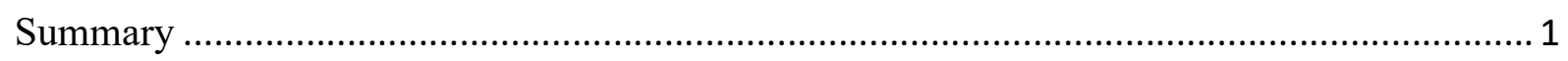

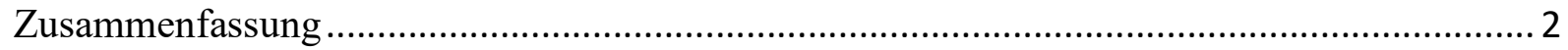

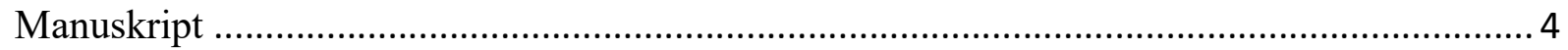

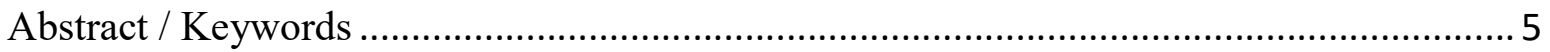

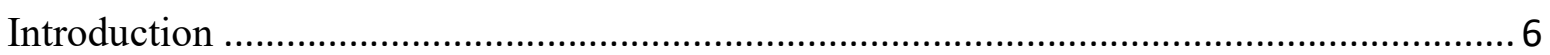

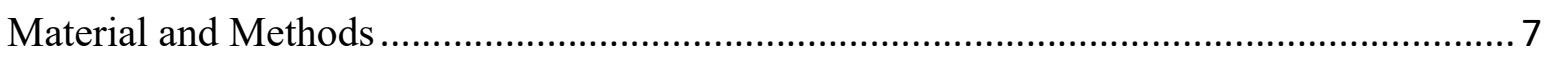

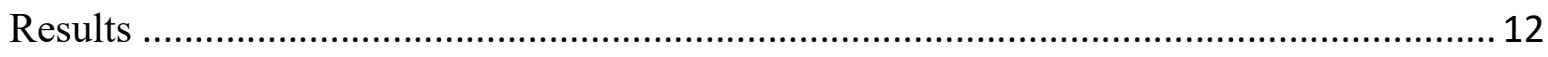

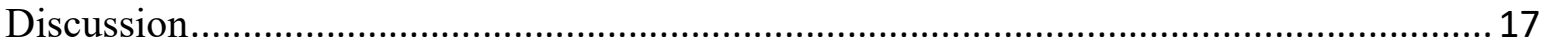

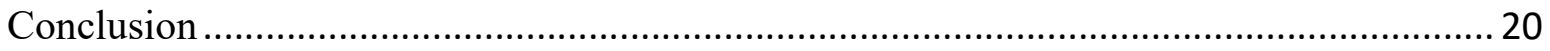

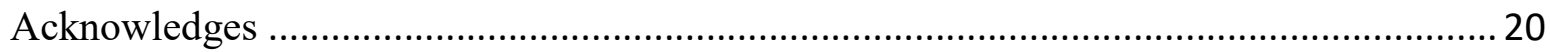

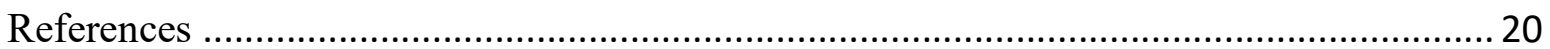

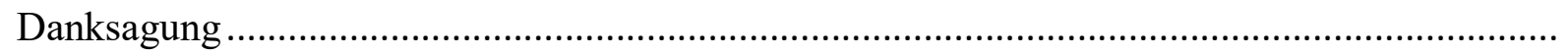

Curriculum vitae 


\section{Summary}

The plasma concentrations of 25-OH-D, 1,25-(OH) $2-\mathrm{D}$, ionized (iCa) and total calcium (tCa) were determined in gentoo penguins (Pygoscelis papua) under three different housing conditions: 1. without ultraviolet (UV) light, with supplementation of 1000 IU vitamin D per animal and day (study period D), 2. without UV-light, without supplementation of vitamin D (Baseline), 3. with UV-light, without supplementation of vitamin D (UVB). The vitamin D contents of fish were measured by high performance liquid chromatography and varied between fish species and between facilities. The average vitamin D intake per animal and day without supplementation were $130 \mathrm{IU}$ (25.5 IU/kg body weight BW) at facility 1, and $2454 \mathrm{IU}$ (438.2 IU/kg BW) at facility 2. The supplementation of vitamin D significantly elevated the plasma concentrations of 25-OH-D by an intra-individual difference of 15 (range -2-59) nmol/1 and tCa by $0.1(0.0-0.3) \mathrm{mmol} / \mathrm{l}$ only at facility 2 . The exposure to UV-light raised the blood concentrations of $\mathrm{tCa}$ at facility 2 by $0.15(0.1-0.2) \mathrm{mmol} / \mathrm{l}$, and of $\mathrm{iCa}$ and $\mathrm{tCa}$ for females at facility 1 by $0.23(0.13-0.41) \mathrm{mmol} / \mathrm{l}$ and $1.8(1.1-2.5) \mathrm{mmol} / \mathrm{l}$, respectively. No significant influence was found for the concentrations of 1,25-(OH) $)_{2}-\mathrm{D}$.

Keywords: penguin, UVB, vitamin D, fish feeding, indoor housing 


\section{Zusammenfassung}

In Eselspinguinen (Pygsoscelis papua) wurden die Plasmakonzentrationen von 25-OH-D, 1,25$(\mathrm{OH})_{2}$-D, ionisiertem Kalzium (iCa) und Totalkalzium ( $\mathrm{tCa}$ ) nach drei verschiedenen Haltungsbedingungen gemessen: 1. ohne Ultraviolett (UV)-Licht, mit Supplementierung von 1000 IU Vitamin D pro Tier und Tag (Studienphase D), 2. ohne UV-Licht, ohne Supplementierung von Vitamin D (Ausgangswerte), 3. mit UV-Licht, ohne Supplementierung von Vitamin D (UVB). Die Vitamin D-Gehalte der Fische wurden mittels Hochleistungsflüssigkeitschromatographie bestimmt. Sie unterschieden sich zwischen den Fischarten wie auch zwischen den zoologischen Einrichtungen. Die durchschnittliche Vitamin D-Aufnahme pro Tier und Tag ohne Supplementierung betrug $130 \mathrm{IU}$ (25.5 IU/kg Körpergewicht KG) in Einrichtung 1 und 2454 IU (438.2 IU/kg KG) in Einrichtung 2. Die Supplementierung von Vitamin D erhöhte signifikant die Plasmakonzentrationen von 25-OH-D um eine intra-individuellen Differenz von 15 (Range -2-59) nmol/1 und tCa um $0.1(0.0-0.3) \mathrm{mmol} / 1$ in Einrichtung 2. Die Bestrahlung mit UV-Licht erhöhte die Plasmakonzentrationen von tCa in Einrichtung 2 um $0.15(0.1-0.2)$ $\mathrm{mmol} / \mathrm{l}$, und von $\mathrm{iCa}$ und $\mathrm{tCa}$ in Weibchen der Einrichtung 1 um 0.23 (0.13-0.41) mmol/1 respektive $1.8(1.1-2.5) \mathrm{mmol} / \mathrm{l}$. Auf die Plasmakonzentrationen von 1,25-(OH) 2 -D wurde kein signifikanter Einfluss gefunden.

Schlüsselwörter: Pinguin, UVB, Vitamin D, Fischfütterung, Innenhaltung 


\section{Manuskript}

Diese Arbeit wurde im Journal of Animal Physiology and Animal Nutrition publiziert:

J Anim Physiol Anim Nutr. 2018; Article ID: JPN12941, DOI: 10.1111/jpn.12941

\section{UV-light and dietary vitamin D and their effects on ionized calcium and 25-OH-D plasma} concentrations in captive gentoo penguins (Pygoscelis papua).

Ursina Tröndle ${ }^{1}$, Hanspeter W. Steinmetz ${ }^{2}$, Simon R. Rüegg ${ }^{3}$, Anja Müller ${ }^{4}$, Annette Liesegang $^{1 *}$

${ }^{1}$ Institute of Animal Nutrition, Vetsuisse Faculty, University of Zurich, Switzerland

${ }^{2}$ Chester Zoo, Chester, UK

${ }^{3}$ Section of Epidemiology, Vetsuisse Faculty, University of Zurich, Switzerland

${ }^{4}$ IDEXX Laboratories, Vet Med Labor GmbH, Ludwigsburg, Germany

* Correspondence: Prof. Dr. med. vet. Annette Liesegang, Dipl. ECVCN, Dipl. IVAS, Institute of Animal Nutrition, Vetsuisse faculty, University of Zurich, Winterthurerstrasse 270, 8057 Zürich, Switzerland. Phone: 00414463588 23, Fax: 004144635 89 39, email: aliese@nutrivet.uzh.ch 


\begin{abstract}
In the present study the effect of ultraviolet (UV) light and dietary vitamin D on calcium metabolism in permanently indoor housed gentoo penguins (Pygoscelis papua) was investigated. The study consisted of three periods, each completed with blood samples to analyse plasma concentrations of 25-OH-D, 1,25-(OH) $2-\mathrm{D}$, ionized (iCa) and total calcium (tCa). During the first study period (D) animals were housed under routine conditions without UV-light and fed a diet of different fish species, supplemented with 1000 IU vitamin D per animal and day. The following study period (Baseline) of 28 days duration consisted of the same diet without any vitamin D supplementation and without UV-light. During the study period (UVB), artificial UV-light was added for 3 weeks. The vitamin D content of fish were measured by high performance liquid chromatography. It varied between fish species and between facilities, ranging from no measurable content in capelin (Mallotus villosus) to 7340 IU vitamin D/kg original matter (OM) in herring (Clupea spp). The average dietary vitamin D content was $311 \mathrm{IU} / \mathrm{kg} \mathrm{OM}$ at facility 1 and $6325 \mathrm{IU} / \mathrm{kg}$ OM at facility 2, resulting in a vitamin D intake per animal and day without supplementation of $130 \mathrm{IU}$ (25.5 IU/kg body weight BW) and $2454 \mathrm{IU}$ (438.2 IU/kg BW), respectively. The supplementation of vitamin D elevated significantly the plasma concentrations of 25-OH-D by an intra-individual difference of 15 (range -2-59) nmol/1 and tCa by $0.1(0.0-0.3) \mathrm{mmol} / 1$ only at facility 2 . The exposure to UVlight raised the blood concentrations of tCa at facility 2 by $0.15(0.1-0.2) \mathrm{mmol} / \mathrm{l}$, and of iCa and $\mathrm{tCa}$ for females at facility 1 by $0.23(0.13-0.41) \mathrm{mmol} / \mathrm{l}$ and $1.8(1.1-2.5) \mathrm{mmol} / \mathrm{l}$, respectively. No significant influence of the study periods (D) and (UVB) was found for the concentrations of $1,25-(\mathrm{OH})_{2}-\mathrm{D}$ at both facilities.
\end{abstract}

Keywords: Penguin, UVB, calcidiol, calcitriol, fish feeding, indoor housing, metabolic bone disease 


\section{Introduction}

Captive gentoo penguins (Pygoscelis papua) are mainly housed in indoor facilities for infectious disease prophylaxis and to provide adequate colder climatic conditions as found in their natural circumpolar habitat. The disadvantage of indoor housing is the lack of natural sunlight and thus lack of ultraviolet (UV) B-light (280-315 nm), which is known to have an influence on vitamin D and calcium metabolism in various avian species (Lupu and Robins, 2013; Schaftenaar and van Leeuwen, 2015; Stanford, 2006b; Woodhouse and Rick, 2016).

Birds can absorb vitamin $\mathrm{D}_{3}$ (cholecalciferol) from the diet or synthesise it endogenously in a UVB-light dependant reaction in the skin. The best indicator of an animal's vitamin D status and its UVB exposure is the blood concentration of 25-OH- $\mathrm{D}_{3}$ (calcidiol), which has a long half-life time of 2 to 3 weeks (Garcia et al., 2013). Its synthesis in the liver is fast, rarely regulated and not influenced by calcium or phosphorus plasma levels. In the kidney, $25-\mathrm{OH}-\mathrm{D}_{3}$ is hydroxylated into $1,25-(\mathrm{OH})_{2}-\mathrm{D}_{3}$ (calcitriol), one of the most active metabolites, which has a short half life time of 6-8 hours (Garcia et al., 2013). This reaction is regulated tightly by calcium and parathyroid hormone (PTH) levels, growth hormone, prolactin and oestrogen as well as by negative feedback. The major role of vitamin D metabolites is the regulation of the calcium metabolism together with PTH and calcitonin, but they can also affect the immune system, the skin or tumour cells (Lumeij, 1994; Matos, 2008; Shojadoost et al., 2015; Stanford, 2003, 2006a, b). In birds, about $99 \%$ of body calcium is stored in bones, and $1 \%$ is extracellular, either bound to proteins (30-40\%) such as albumin and vitellogenin forming a physiological inactive storage pool, or ionized (60-70\%) to the physiological active form (iCa) (Lumeij, 1994; Matos, 2008; Stanford, 2006a). Plasma concentrations of total calcium (tCa) are affected directly by changes in the concentration of calcium-binding proteins and in the female within the reproductive status. In contrast, in poultry iCa levels during the egg-laying period are similar to the non-egg-laying period and are maintained within a narrow, species-specific range (Matos, 2008; Stanford, 2006a). Hyper- and hypocalcaemia and hypervitaminosis or hypovitaminosis D are reported in various bird species (Nain et al., 2007; Tangredi and Krook, 1999; Cousquer et al., 2007; Stanford, 2007; Olds et al., 2015; Woodhouse and Rick, 2016). Total calcium levels as high as $9.98 \mathrm{mmol} / 1$ (40 mg/dl) can be physiologically observed during the egg laying process due to increased oestrogen production and production of calcium-binding proteins (Matos, 2008).

Recommended and toxic levels of dietary vitamin D and required UVB radiation for vitamin $\mathrm{D}_{3}$ photoconversion are unknown for most avian species. They likely differ according to 1) the 
original ecological niche of the species, or 2) the UVB radiation in the natural habitat, and are influenced by e.g. melanin, feathers and cholesterol (Schaftenaar and van Leeuwen, 2015; Lupu and Robins, 2013). Estimates of the vitamin D requirements for bird species differ greatly ranging for example from 200-500 IU/kg diet dry matter (DM) for ducks and geese (National Research Council USA, 1987) to 2800 IU/kg for broiler chickens (Atencio et al., 2006; Jiang et al., 2015). According to the Council of the European Union (1970), a maximal level of 3000 $\mathrm{IU} / \mathrm{kg}$ diet for laying hens should not be exceeded. Animals might tolerate vitamin D levels of 4-10 times the requirement over a long period before suffering from intoxication (National Research Council USA, 1987; Crissey et al., 2005). Nevertheless, extrapolating vitamin D requirements from poultry to other bird species bears significant dangers. It is suggested that birds with adequate exposure to direct sunlight have no requirement for dietary vitamin D (Matos, 2008; National Research Council USA, 1987). Vitamin D intoxication due to excessive exposure to UVB radiation has not been reported, as cholecalciferol is degraded in a UVdependent reaction into inert compounds (Stanford, 2006b). Nevertheless, care should be taken with the provision of artificial UVB-light due to other dangers as tissue and DNA damages (eg photokeratitis and photodermatitis).

Although this data scarcity includes penguins, the American Zoo and Aquarium Association (AZA) Penguin Taxon Advisory Group (Crissey et al., 2005) suggested that penguins do not need calcium or vitamin D supplements, given that the content of calcium in whole fish and krill $(0.9-6.4 \% \mathrm{DM})$ is higher than the required minimum calcium concentration of $0.8 \% \mathrm{DM}$. However, metabolic bone disease (MBD) was reported in captive juvenile Humboldt penguins (Spheniscus humboldti) kept indoors (Adkesson and Langan, 2007). To the authors' knowledge, no values for iCa and 1,25-(OH) 2 -D exist for any species in the order Pygoscelis.

The object of this study was to investigate the effect of UV-light and dietary vitamin D on plasma concentrations of 25-OH-D, 1,25- $(\mathrm{OH})_{2}-\mathrm{D}$, iCa and $\mathrm{tCa}$ in gentoo penguins, testing the hypothesis that penguins kept indoors need additional UVB-light and / or dietary vitamin D supplementation.

\section{Material and Methods}

\section{Animals and housing}

The study was conducted at two different zoological facilities housing gentoo penguins in permanent indoor enclosures without measurable UVB-irradiance. Animals at both facilities 
had no access to natural sunlight. At facility 1, artificial light imitating the seasonal variation in the natural habitat was provided, and the light intensity was altered as in nature by clouds. Artificial rain was provided regularly. The air temperature was constant at $8{ }^{\circ} \mathrm{C}$, and the water temperature at $6{ }^{\circ} \mathrm{C}$ during winter and $8.5^{\circ} \mathrm{C}$ during summer. At facility 2 , artificial light was provided during the study period from 0600 to 1800 hours and a machine producing artificial ice was running constantly. The air temperature was constant at $10{ }^{\circ} \mathrm{C}$, and the water temperature at $7.5^{\circ} \mathrm{C}$.

The subjects at facility 1 were ten healthy adult gentoo penguins (six males and four females) aging from 8 to 18 years (median 9.5 years), and at facility 2 fourteen adult gentoo penguins (six males and eight females) aging from 4 to 22 years (median 9 years).

\section{Nutrition and nutritional analysis}

At both facilities, fish were stored at $-21^{\circ} \mathrm{C}$ for an average of one to two months and thereafter defrosted in the cold storage room at $6-8{ }^{\circ} \mathrm{C}$ and fed within $24-48 \mathrm{hr}$. The average diet consumed was calculated from the measured total amount of fish fed to the whole group during 21 days at facility 1 and 11 days at facility 2, respectively, with the presumption that every animal ate the same amount of each fish species (Table 1). Both facilities fed twice a day, while facility 2 inserted a fasting day every week. Penguins from facility 1 consumed an average of $418 \mathrm{~g}$ fish per animal and day with an individually fed vitamin D supplement (1000 IU/animal and day, Aquaminivits, Zoovet Products, West Yorkshire BD21 4NQ, UK), while penguins from facility 2 consumed an average of $388 \mathrm{~g}$ fish per animal and day with vitamin D supplement equally sprinkled over all fishes (1000 IU/animal and day, Mazuri Fish Eater Tablets, Claus GmbH, Friedensau 11, 67117 Limburgerhof). At the end of the study, a frozen sample of each fish species from facility 1 was sent overnight in a styrofoam box with cooling elements to LUFA-ITL GmbH, Kiel, Germany for vitamin D analyses. At the time of the second blood sampling, samples of herring and Atlantic mackerel (Scomber scombrus) from facility 2 were thawed as usual, crushed with a mixer, frozen again, and thereafter sent frozen on dry ice to the same laboratory. All samples were analysed on original matter $(\mathrm{OM})$ for vitamin $\mathrm{D}_{3}$ content by reverse phase high performance liquid chromatography (HPLC) with UV detection (method VDLUFA III, 13.8.1), a modification of the standardised method DIN EN 12821 (Deutsches Institut für Normung (DIN), 2009). After saponification with an alcoholic potassium hydroxide solution and extraction with petroleum, the obtained samples were 
Table 1: Diet composition, vitamin D content of fish species and daily vitamin D intake per gentoo penguin (Pygoscelis papua) at two zoological facilities.

\begin{tabular}{|c|c|c|c|c|c|c|c|c|}
\hline & \multicolumn{4}{|c|}{ Facility 1} & \multicolumn{4}{|c|}{ Facility 2} \\
\hline & $\begin{array}{l}\text { Gram / } \\
\text { animal / } \\
\text { day }^{\text {a }}\end{array}$ & $\begin{array}{l}\% / \\
\mathrm{kg} \\
\text { diet }\end{array}$ & $\begin{array}{l}\text { vitamin } \\
\mathrm{D}(\mathrm{IU}) / \\
\mathrm{kg} \mathrm{fish}{ }^{\mathrm{b}}\end{array}$ & $\begin{array}{l}\text { vitamin D } \\
\text { (IU) / } \\
\text { animal / } \\
\text { day }\end{array}$ & $\begin{array}{l}\text { Gram / } \\
\text { animal / } \\
\text { day }^{\text {a }}\end{array}$ & $\begin{array}{l}\% / \\
\mathrm{kg} \\
\text { diet }\end{array}$ & $\begin{array}{l}\text { vitamin } \\
\mathrm{D}(\mathrm{IU}) / \\
\mathrm{kg} \mathrm{fish}{ }^{\mathrm{b}}\end{array}$ & $\begin{array}{l}\text { vitamin D } \\
\text { (IU) / } \\
\text { animal / } \\
\text { day }\end{array}$ \\
\hline $\begin{array}{l}\text { Herring } \\
\text { (Clupea harengus } \\
\text { membras) }{ }^{\mathrm{c}}\end{array}$ & 80 & 19.1 & 1400 & 112 & 152 & 39.2 & 7340 & 1116 \\
\hline $\begin{array}{l}\text { Capelin } \\
\text { (Mallotus } \\
\text { villosus) }\end{array}$ & 330 & 79.0 & $\mathrm{~nm}^{\mathrm{d}}$ & 0 & -- & -- & -- & -- \\
\hline $\begin{array}{l}\text { Sprat } \\
\text { (Sprattus sprattus) }\end{array}$ & 8 & 1.9 & 2190 & 18 & 122 & 31.4 & $4204^{e}$ & 513 \\
\hline $\begin{array}{l}\text { Mackerel } \\
\text { (Scomber } \\
\text { scombrus) }\end{array}$ & -- & -- & 2050 & -- & 114 & 29.4 & 7240 & 825 \\
\hline Total & 418 & & & 130 & 388 & & & 2454 \\
\hline Supplementation & & & & $1000^{f}$ & & & & $1000^{\mathrm{g}}$ \\
\hline $\begin{array}{l}\text { Total vitamin D } \\
\text { intake }\end{array}$ & & & & 1130 & & & & 3454 \\
\hline
\end{tabular}

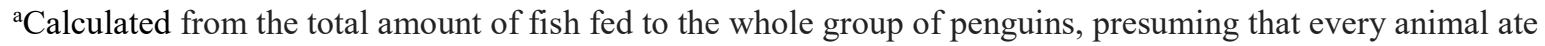
the same amount of each fish species.

${ }^{b}$ Examined on original matter by high performance liquid chromatography at LUFA-ITL GmbH, Kiel, Germany. 'Species not known for facility 2.

${ }^{d}$ not measurable, below the detectable threshold of the laboratory of $1000 \mathrm{IU} / \mathrm{kg}$ fish.

enot analysed, value from the literature (Stancheva et al., 2010).

${ }^{\mathrm{f}}$ Aquaminivits, Zoovet Products, West Yorkshire BD21 4NQ, UK, 2 tablets per animal and day, fed individually. 'Mazuri Fish Eater Tablets, Claus GmbH, Friedensau 11, 67117 Limburgerhof, 1/2 tablet per animal and day, fed non-individually.

purified using a preparative HPLC. Thereafter, the vitamin D contents were quantified by reverse phase HPLC with UV detection and the results corrected by the recovery rate of the internal standards. Vitamin $\mathrm{D}_{2}$ was used as internal standard for the measurement of vitamin $\mathrm{D}_{3}$ and vice versa. The minimum detectable content of vitamin $\mathrm{D}_{3}$ was $1000 \mathrm{IU} / \mathrm{kg}$. At facility 2 , no sprat was analysed and a content of 4204 IU vitamin D provided in the literature was assumed for calculation (Stancheva et al., 2010). 


\section{Study design}

The study was conducted with the permissions of the official governmental animal welfare councils (facility 1 permit 35-9185.81/G-15/131, facility 2 permit 84-02.04.2015.A094) between January and March and were in accordance to the German Protection of Animal Law. The study consisted at both facilities of three phases, each completed with a blood sample. Study period (D) was the routine housing, where animals were fed their common diet and vitamin D supplementation (Table 1). During the following study period (Baseline)of 28 days duration, no vitamin D supplements and UV-light were provided to establish the baseline values. Thereafter, during the study period (UVB), still no vitamin D supplements were fed but artificial UV-light was additionally provided. At each time of blood sampling, a clinical examination including weighing was performed for all animals and the UVB irradiance was measured using a solarmeter (Model 6.2 UVB, Solartech, Glenside PA 19038, USA, response 280-322nm, resolution $1 \mu \mathrm{W} / \mathrm{cm}^{2}$ ). UVB irradiance was measured weekly during the study period (UVB).

At facility 1 , the routinely fed vitamin $\mathrm{D}$ supplements were replaced during the study period (Baseline) by products containing vitamin B and E (Vitamin B12, $100 \mu \mathrm{g} /$ tablet, Revomed Gmbh, 38855 Wernigerode, Germany, $1 / 2$ tablet per animal and day; VITA Vitamin E forte 268 mg, Ascopharm Gmbh, 38845 Wernigerode, Germany, 1 capsule per animal every $4^{\text {th }}$ day). Artificial UV-light was provided during 26 days by installing seven UV-lamps (UV-compact 26W 10.0, X-Reptile, Winterthur, Switzerland) with reflector shields in the exhibition enclosure above the main resting spots of the animals. UVB irradiance was not equally distributed in the enclosure, ranging from no detectable in the corner to a maximum under the lamps in the middle of the enclosure of $5 \mu \mathrm{W} / \mathrm{cm}^{2}$ at ground level and $8 \mu \mathrm{W} / \mathrm{cm}^{2}$ at animal level, which was defined as $40 \mathrm{~cm}$ above ground. The animals had free access to the pool. During the first seven days, the exposure time was continuously extended from one hour to the final 8 to 9 hours to allow the animals to get used to the UV-lamps. The final daily radiation dose at animal level varied depending on the location from 0 to $260 \mathrm{~mJ} / \mathrm{cm}^{2}$.

At facility 2, no additional supplements were fed during the study period (Baseline). During the 21 days of the study period (UVB), four opportunistically selected animals (1.3) were separated in the quarantine area, where UV-light was provided by four identical UV-lamps measuring a constant irradiance of $7.0 \mu \mathrm{W} / \mathrm{cm}^{2}$ at ground level and $9.0 \mu \mathrm{W} / \mathrm{cm}^{2}$ at animal level equally distributed in the whole area. After continuously prolonging the exposure time during the first 
seven days, the lamps were switched on 6 hours per day resulting in a radiation dose of 194 $\mathrm{mJ} / \mathrm{cm}^{2}$ at animal level for the subsequent 14 days.

\section{Blood sampling and biochemistry analyses}

The animals were manually restrained in ventral recumbency and blood was taken from the dorsal coccygeal vein ( $V$. coccygealis dorsalis) using a $3 \mathrm{ml}$ blood gas analysis syringe (BD ALine $^{\mathrm{TM}}$, syringe containing 80 units of heparin, Becton Dickinson GmbH, Heidelberg, Germany) with a 21 or $22 \mathrm{G}$ needle.

Concentrations of iCa were determined immediately on site using a portable analyser iSTAT with EG7+ cartridge (Axonlab, 5405 Baden-Daettwil, Switzerland). This technique has already been evaluated in chickens (Gallus gallus; Steinmetz et al., 2007). The remaining blood was centrifuged, and the plasma sent to the reference laboratory (Vet Med Labor GmbH, Division of IDEXX Laboratories, Ludwigsburg, Germany). Plasma concentrations of albumin, tCa and total protein were measured using a clinical chemistry system (Beckman Coulter's AU5800, Krefeld, Germany). Plasma concentrations of 25-OH-D were determined on a U-HPLC system (Dionex 3000 Rapid Separation LC, Thermo Fisher Scientific, Waltham MA 02451, USA) with a diode array detector (detection wavelength $265 \mathrm{~nm}$ ). This method was found to be reliable to detect 25-OH-D in different species such as cattle, pigs, poultry, mink, horse and humans (Hymoller and Jensen, 2011). Plasma concentrations of 1,25-(OH) $-\mathrm{D}$ were analysed by radioimmunoassay (RIA), a method already used in chickens (Sedrani, 1984; Lietzow et al., 2012) or African grey parrots (Psittacus e erithacus; Stanford, 2007).

\section{Statistical analyses}

Statistical analysis was performed using the software R 3.3.0 (R Core Team, 2016). Regarding the small sample size, descriptive statistics are presented as median (range). The association of blood parameters with study (compared to study period (Baseline)), sex and age was evaluated using a mixed effect model (R package "nlme") with individuals as random effect (Pinheiro et al., 2016) of the form "Ime(outcome Study+Age+Sex+Study*Sex|Individual)", where outcome was blood concentrations of $25-\mathrm{OH}-\mathrm{D}, 1,25-(\mathrm{OH})_{2}-\mathrm{D}, \mathrm{iCa}, \mathrm{tCa}$, albumin or total protein. The study periods (D) and (UVB) were compared using the same model, excluding the data of the study period (Baseline). A threshold of $p<0.05$ was regarded statistically significant. Statistical analysis were performed for each facility separately. 


\section{Results}

\section{Nutrition}

The vitamin D content in fish varied between species and between the facilities, ranging from no measurable in capelin to $7340 \mathrm{IU} / \mathrm{kg}$ in herring at facility 2 (Table 1). According to the composition and average consumption, the diet contained $311 \mathrm{IU}$ vitamin D/kg OM at facility 1 and $6325 \mathrm{IU}$ vitamin $\mathrm{D} / \mathrm{kg} \mathrm{OM}$ at facility 2, resulting in a vitamin D intake per animal and day without supplementation of $130 \mathrm{IU}$ (25.5 IU/kg body weight BW) and 2454 IU (438.2 IU/kg BW), respectively (Table 1).

\section{Facility 1}

All penguins were healthy on the three clinical examinations during the study. Body weights were $4.15(3.5-5.1) \mathrm{kg}$ at the end of study period (D), $5.85(5.1-7.8) \mathrm{kg}$ at the end of study period (Baseline) and 4.7 (4.1-6.2) $\mathrm{kg}$ after the study period (UVB). During the trial period (UVB), the animals showed their normal behaviour, often resting at their preferred spots under the UV-lamps. The keeper observed them swimming in the pool mainly as usual around midday and after the lamps were switched off in the evening. Five and 6 days prior to the third blood sampling, additional small rocks were provided in the enclosure and penguins started to build nesting sites.

Nearly one third of the blood values (43/180) were missing due to insufficient blood volume. Baseline values were 43 (37-68) nmol/1 for 25-OH-D ( $\mathrm{n}=7), 7.1(5.0-11.8) \mathrm{pg} / \mathrm{ml}$ for 1,25$(\mathrm{OH})_{2}-\mathrm{D}(\mathrm{n}=7), 1.16(0.93-1.37) \mathrm{mmol} / \mathrm{l}$ for $\mathrm{iCa}(\mathrm{n}=9), 2.6(2.4-2.7) \mathrm{mmol} / \mathrm{l}$ for $\mathrm{tCa}(\mathrm{n}=7), 1.8$ $(1.6-2.0) \mathrm{g} / \mathrm{dl}$ for albumin $(\mathrm{n}=7)$ and $4.6(4.2-5.2) \mathrm{g} / \mathrm{dl}$ for total protein $(\mathrm{n}=7)$. Age had no significant influence on any of the blood parameters. Significantly higher iCa values were found in males than females ( $\mathrm{p}=0.0039)$. Baseline values of all measured blood parameters split by sex are shown in Figure 1. 

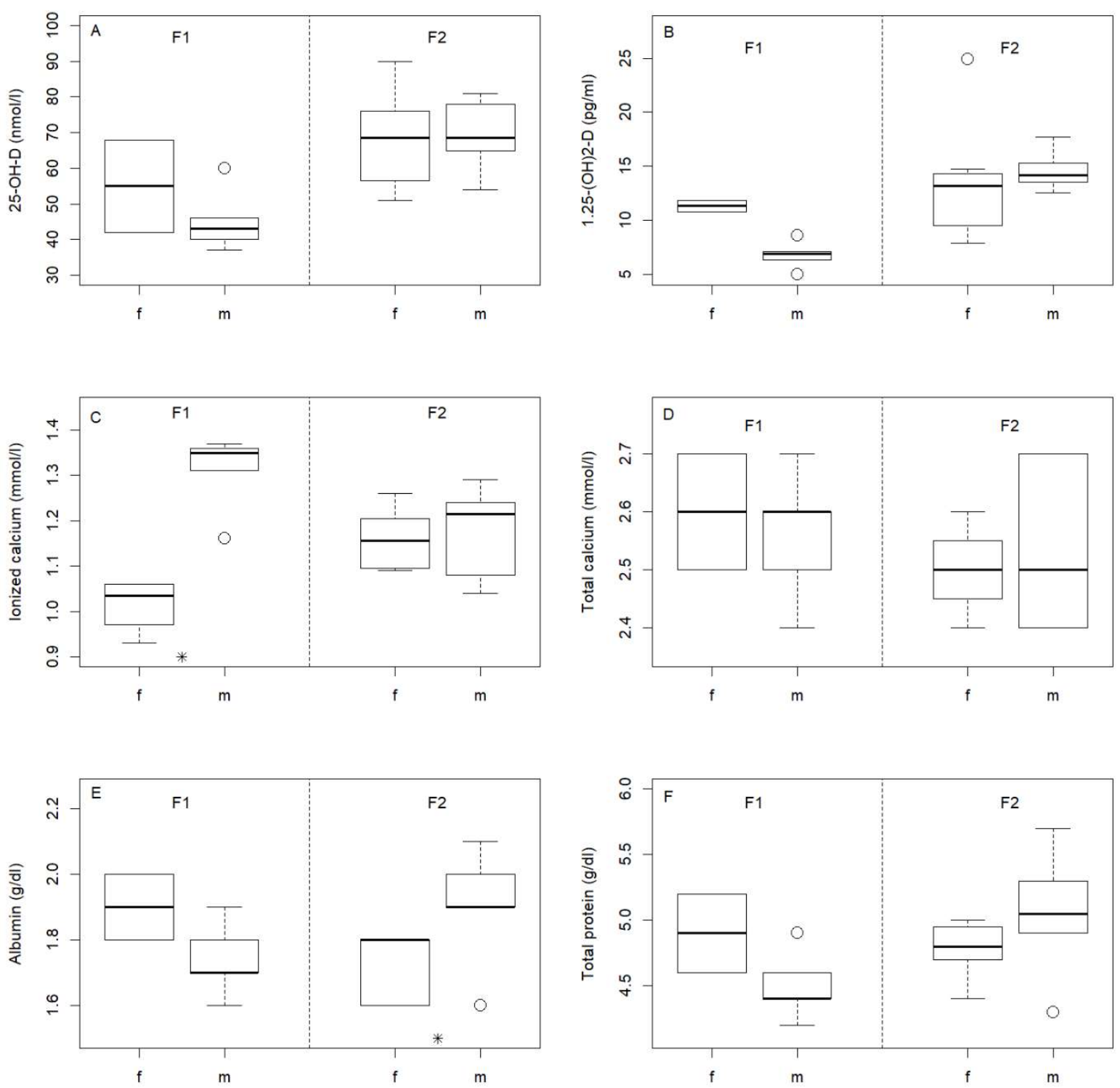

Figure 1: Baseline plasma values of 25-OH-D (A), 1,25-(OH)2-D (B), ionized calcium (C), total calcium (D), albumin (E) and total protein (F) in gentoo penguins (Pygoscelis papua) at two different zoological facilities (F1 and F2). X-axis split by female (f) and male (m). Significant $(\mathrm{p}<0.05)$ sex differences are marked by an asterix (*). The box extends between the 1rst and the 3rd quartile with the median as bold line, the whiskers represent the values within further 1.5 of interquartile range and dots are more extreme values.

In females, the exposure to UV-light raised significantly the blood concentrations of iCa by an intra-individual difference of $0.23(0.13-0.41) \mathrm{mmol} / 1$ and tCa $1.8(1.1-2.5) \mathrm{mmol} / \mathrm{l} \mathrm{compared}$ to the baseline values and tCa $1.40(0.8-2.0) \mathrm{mmol} / \mathrm{l}$ also compared to the study period (D). The supplementation of vitamin D elevated the values of albumin $0.2(0.0-1.1) \mathrm{g} / \mathrm{dl}$ and total protein $0.6(0.1-2.7) \mathrm{g} / \mathrm{dl}$ in both sexes significantly from the baseline values. No significant 
influence of the study periods (D) and (UVB) was found for the concentrations of 25-OH-D and 1,25-(OH) $2-\mathrm{D}$. For all measured blood parameters, details for the significant results of the mixed effect model are shown in Table 2 and for the significant intra-individual differences between the different study periods in Figure 2.

Table 2: Results of the linear mixed effect models with individuals as random effect investigating the effects of age, sex and the study periods (Baseline) (no vitamin D supplementation, no UVB-light), (D) (1000 IU vitamin D/animal and day, no UVB-light) and (UVB) (no vitamin D supplementation, artificial UVBlight of 0 to $\left.260 \mathrm{~mJ} / \mathrm{cm}^{2}\right)$ on the plasma concentrations of $25-\mathrm{OH}-\mathrm{D}, 1,25-(\mathrm{OH})_{2}-\mathrm{D}$, ionized calcium, total calcium, albumin and total protein in gentoo penguins (Pygoscelis papua) at two different zoological institutions. Only significant results are reported.

\begin{tabular}{|c|c|c|c|c|}
\hline \multicolumn{5}{|c|}{ Facility 1} \\
\hline & & Beta $^{a}$ & $\mathrm{SE}^{\mathrm{b}}$ & p-Value \\
\hline \multirow[t]{4}{*}{ Ionized calcium } & UVB (Reference: Baseline) & 0.250 & 0.060 & 0.0013 \\
\hline & Male (Reference: Female) & 0.280 & 0.066 & 0.0039 \\
\hline & Male : D & -0.282 & 0.085 & 0.0063 \\
\hline & Male : UVB & -0.231 & 0.081 & 0.0144 \\
\hline \multirow[t]{3}{*}{ Total calcium } & UVB (Reference: Baseline) & 1.528 & 0.244 & 0.0001 \\
\hline & UVB (Reference: D) & 1.233 & 0.274 & 0.0109 \\
\hline & Male : UVB & -1.353 & 0.301 & 0.0015 \\
\hline Albumin & D (Reference: Baseline) & 0.556 & 0.225 & 0.0357 \\
\hline Total protein & D (Reference: Baseline) & 1.560 & 0.482 & 0.0102 \\
\hline \multicolumn{5}{|c|}{ Facility 2} \\
\hline $25-\mathrm{OH}-\mathrm{D}$ & D (Reference: Baseline) & 18.875 & 6.400 & 0.0113 \\
\hline \multirow[t]{3}{*}{ Total calcium } & UVB (Reference: Baseline) & 0.182 & 0.044 & 0.0013 \\
\hline & D (Reference: Baseline) & 0.113 & 0.031 & 0.0027 \\
\hline & Age & 0.018 & 0.008 & 0.0483 \\
\hline Albumin & Male (Reference: Female) & 0.172 & 0.059 & 0.0140 \\
\hline Total protein & D (Reference: Baseline) & 0.288 & 0.113 & 0.0245 \\
\hline
\end{tabular}

aProbability of making a type II error in a hypothesis test.

bStandard Error.

${ }^{\mathrm{c}}$ Calculated probability. 

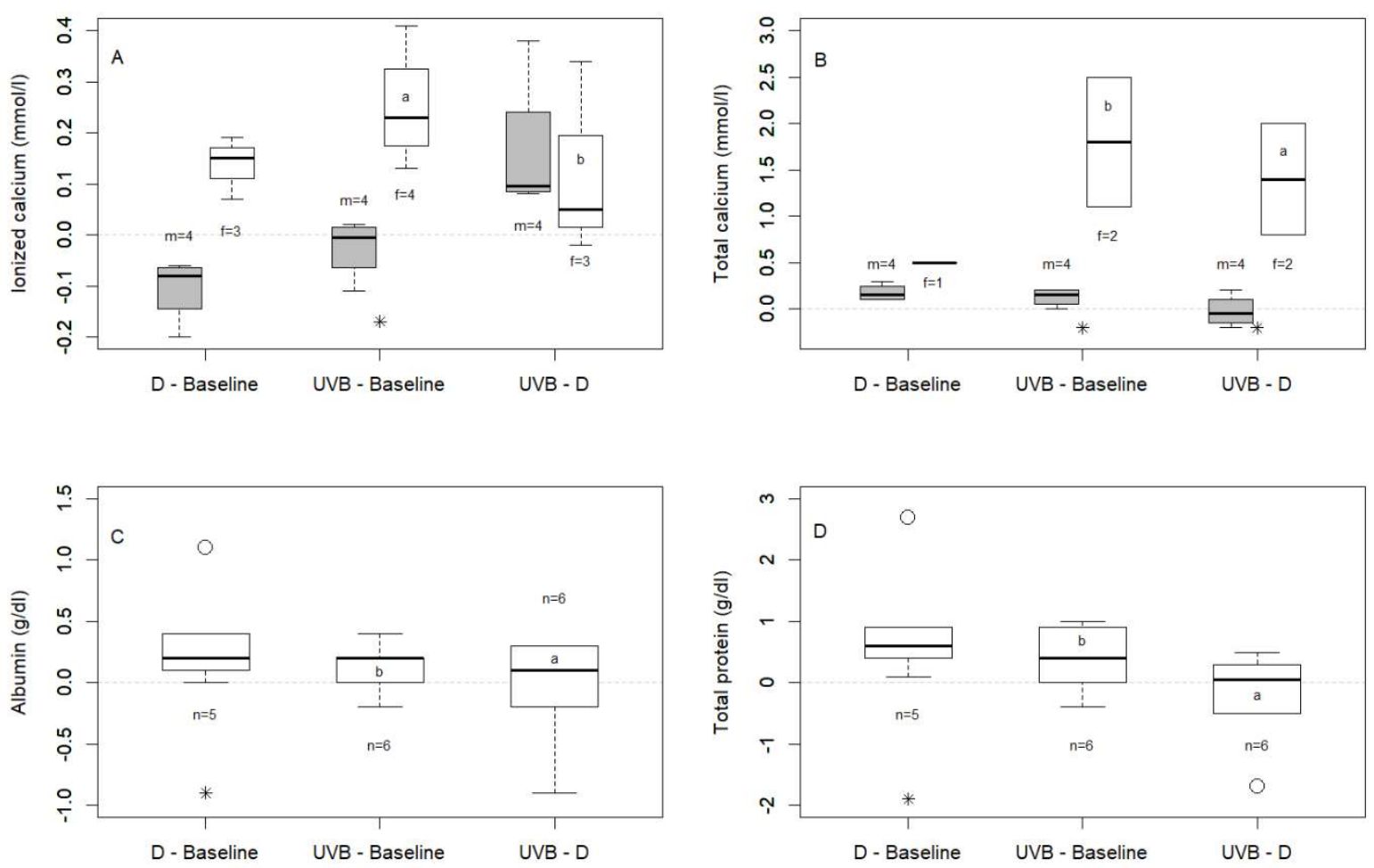

Figure 2: Effect of vitamin D supplementation (1000 IU vitamin D/animal and day, no UVB-light), or UVBlightning (no vitamin D supplementation, artificial UVB-light of 0 to $260 \mathrm{~mJ} / \mathrm{cm}^{2}$ ) compared mutually and to baseline values in gentoo penguins (Pygoscelis papua) at Facility 1. Plotted are the intraindividual differences only for the measured blood parameters with significant findings ( $\mathrm{p}<0.05$, marked with an asterix *): ionized calcium (A), total calcium (B), albumin (C) and total protein (D). Sex affected calcium values significantly, but not albumin and total protein. Two females showed nesting behaviour at the end of study period (UVB) (a), but in some analyses only one sample was included (b). The box extends between the 1rst and the 3rd quartile with the median as bold line, the whiskers represent the values within further 1.5 of interquartile range and dots are more extreme values.

\section{Facility 2}

All penguins were healthy on all clinical examinations during the study. Body weights were 5.7 (4.4-6.9) $\mathrm{kg}$ at the end of study period (D), 5.6 (4.3-6.6) $\mathrm{kg}$ at the end of study period (Baseline) and 5.2 (4.9-5.3) $\mathrm{kg}$ for the four separated animals after the study period (UVB).

At facility two $2.7 \%$ values (5/192) were missing. The baseline values $(n=14)$ were $68.5(51-$ 90) $\mathrm{nmol} / \mathrm{l}$ for 25-OH-D, 13.7 (7.9-24.9) $\mathrm{pg} / \mathrm{ml}$ for 1,25-(OH) $2-\mathrm{D}, 1.20$ (1.04-1.29) $\mathrm{mmol} / \mathrm{l}$ for $\mathrm{iCa}, 2.5(2.4-2.7) \mathrm{mmol} / \mathrm{l}$ for $\mathrm{tCa}, 1.8(1.6-2.1) \mathrm{g} / \mathrm{dl}$ for albumin and 4.9 (4.3-5.7) $\mathrm{g} / \mathrm{dl}$ for total protein. A significant $(\mathrm{p}=0.014)$ sex difference was found for albumin with higher values for 
males than females, and tCa was significantly influenced by the age of the animal $(p=0.048)$. Baseline values of all measured blood parameters split by sex are shown in Figure 1.

The supplementation of vitamin D increased significantly the serum concentrations of 25-OH$\mathrm{D}$ by an intra-individual difference of $15(-2-59) \mathrm{nmol} / \mathrm{l}$, tCa $0.1(0.0-0.3) \mathrm{mmol} / \mathrm{l}$, and total protein $0.3(-0.2-0.6) \mathrm{g} / \mathrm{dl}$ compared to the study period (Baseline). Total calcium $0.15(0.1-$ 0.2) $\mathrm{mmol} / \mathrm{l}$ was significantly elevated by the provision of UV-light compared to the baseline values. No significant influence of the study periods (D) and (UVB) was found for the concentrations of 1,25-(OH) $-\mathrm{D}$ and iCa. For all measured blood parameters, details for the significant results of the mixed effect model are shown in Table 2 and for the significant intraindividual differences between the different study periods in Figure 3.
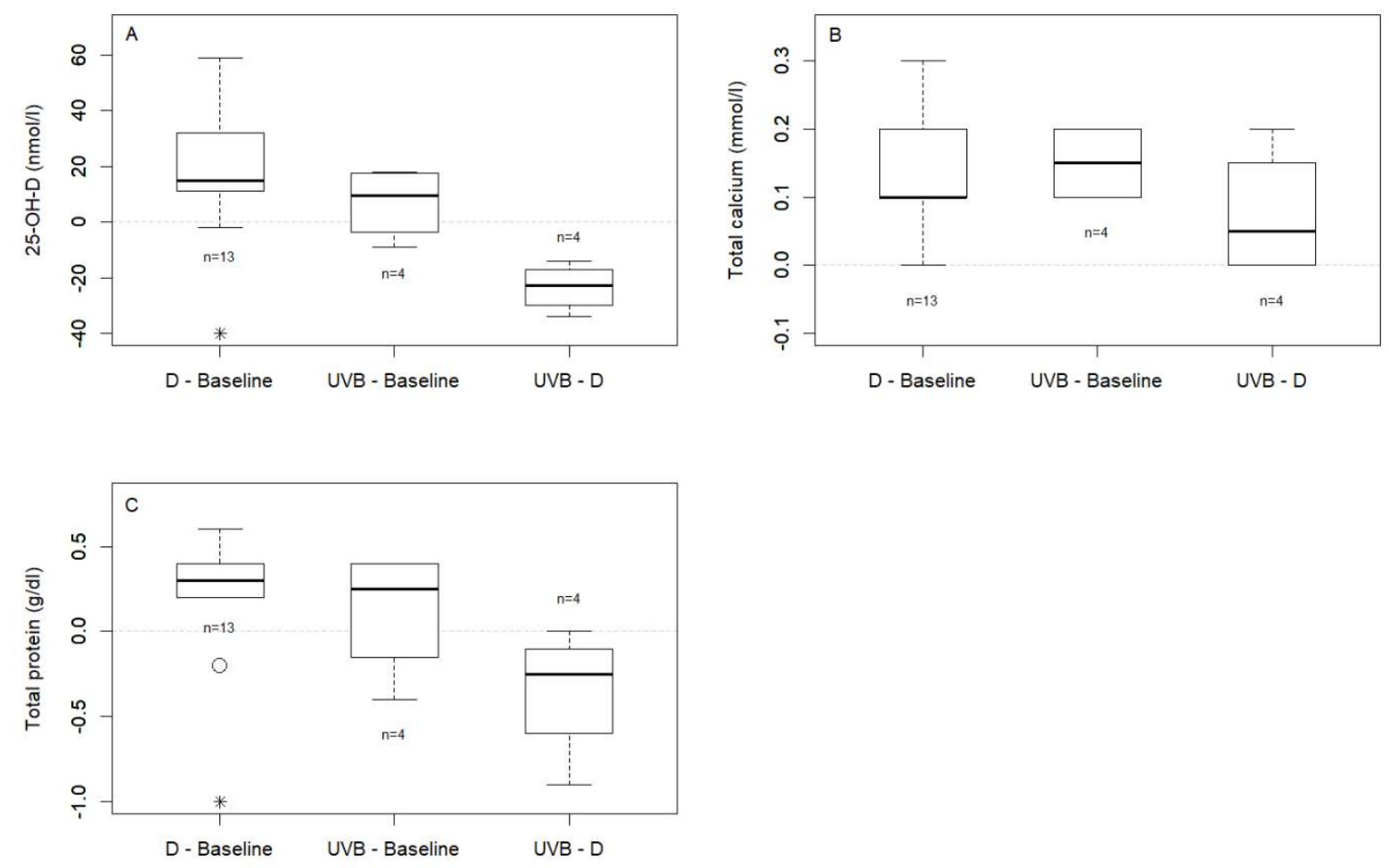

Figure 3: Effect of vitamin D supplementation (1000 IU vitamin D/animal and day, no UVB-light), or UVBlightning (no vitamin D supplementation, artificial UVB-light of $194 \mathrm{~mJ} / \mathrm{cm}^{2}$ ) compared mutually and to baseline values in gentoo penguins (Pygoscelis papua) at Facility 2. Plotted are the intra-individual differences only for the measured blood parameters with significant findings $(p<0.05$, marked with an asterix *): 25-OH-D (A), total calcium (B) and total protein (D). Sex did not affect these parameters significantly. The box extends between the 1rst and the 3rd quartile with the median as bold line, the whiskers represent the values within further 1.5 of interquartile range and dots are more extreme values. 


\section{Discussion}

In the presented study, plasma concentrations of $1,25-(\mathrm{OH})_{2}-\mathrm{D}$ at both facilities were not influenced by any analysed factor, whereas 25-OH-D increased with the supplementation of vitamin D at facility 2. Artificial UV-light elevated serum concentrations of tCa at facility 2, and of $\mathrm{iCa}$ and $\mathrm{tCa}$ for females at facility 1 . The differences found in the vitamin D content of the diets might have influenced the results.

The vitamin D content varied greatly between the fish species examined as well as between the facilities, resulting in a 19-times higher vitamin D intake per animal and day at facility 2 . The low average intake at facility 1 resulted mainly due to the diet composition of about $75 \%$ capelin during the study, and might be underestimated as a content of $0 \mathrm{IU} / \mathrm{kg}$ was used for calculation, but capelin could contain vitamin $D$ under the threshold of the laboratory. If assuming a content of $463 \mathrm{IU} / \mathrm{kg}$ as reported by the AZA Nutrition Advisory Group Handbook (Bernard, 1997), the vitamin D intake per animal and day at facility 1 would still be nearly 9 times lower than at facility 2. Few studies on the vitamin D content of whole fishes exist. It can be influenced by area or time of capture, species, total lipid content, age, gender, stage of life cycle (Bernard, 1997; Worthy, 2001; Stancheva et al., 2010) as well as by transportation, storage and thawing practice. Nevertheless, several studies showed that there were no significant losses of vitamin D in different fish species after cooking or freezing up to 9 months (Dobreva et al., 2013; Matilla et al., 1999; Sahari et al., 2014). In contrast, the vitamin D content in mackerels and sauries was reduced by solar drying (Suzuki et al., 1988). The AZA Nutrition Advisory Group Handbook (Bernard, 1997) provides vitamin D contents in herring (2240 IU/kg) and Atlantic mackerel (4520 IU/kg) which are in between the measured contents in this study. No studies about the vitamin D intake of free-living gentoo penguins exist and analysis of main prey species such as lobster krill (Munida gregaria), rock cod (Patogonotothen ramsayi) and squid (Loligo gahi; Clausen and Pütz, 2002, 2003) are absent. The AZA Penguin Taxon Advisory Group (Crissey et al., 2005) proposed a minimum concentration of $500 \mathrm{IU}$ vitamin $\mathrm{D} / \mathrm{kg}$ diet $\mathrm{DM}$ for adult penguins. Assuming an average of $25 \% \mathrm{DM}$ of the diet, this calculates to a proposed vitamin D content of $125 \mathrm{IU} / \mathrm{kg} \mathrm{OM}$, which is far lower than the observed contents in this study.

The baseline values of $\mathrm{tCa}$ and albumin were comparable to the concentrations of free-living gentoo penguins (Ghebremeskel et al., 1989), and within the reference ranges provided by ISIS (Teare, 2013). No reference values for gentoo penguins exist for $\mathrm{iCa}$. The range of $\mathrm{iCa}$ concentrations in the current study were similar to slightly lower to the concentrations obtained from captive Humboldt penguins housed indoors (Adkesson and Langan, 2007). Baseline 25- 
OH-D values were comparable to the concentrations found in free-living Adélie penguins $(P$. adeliae; Griffiths and Fairney, 1988), but about ten times higher than values reported for clinically healthy Humboldt penguins (Adkesson and Langan, 2007), and also higher than in healthy marabou storks (Leptoptilos crumeniferus; Schaftenaar and van Leeuwen, 2015) or thick-billed parrots (Rhynchopsitta pachyrhyncha; Howard et al., 2004). In contrast, baseline concentrations of $1,25-(\mathrm{OH})_{2}-\mathrm{D}$ found in this study were about 4 to 6 times lower than in growing white Leghorn chicks (Sedrani, 1984) or in marabou stork fledglings (Schaftenaar and van Leeuwen, 2015). No values are reported in the order Sphenisciformes. As whole fishes contain adequate levels of calcium, there might be a lower need of this most active vitamin D metabolite for the up-regulation of the calcium metabolism in penguins. The concentrations of both vitamin D metabolites measured at facility 2 were higher than at facility 1 . The most likely explanation for these findings is the vitamin D content of the diet. As the synthesis of 25-OH$\mathrm{D}$ is rarely regulated, its blood concentrations correlate well with dietary vitamin D intake (Stanford, 2007). This has also been shown in different studies in poultry (Lietzow et al., 2012; Tsang and Grunder, 1993; Jiang et al., 2015). In contrast, an increase of 1,25-(OH)2-D, which has a slow and well-regulated synthesis, could only be observed in white Leghorn hens when supplementing $1100 \mathrm{IU}$ vitamin $\mathrm{D} / \mathrm{kg}(27.5 \mu \mathrm{g} / \mathrm{kg})$ to a vitamin D free diet, whereas doubling the vitamin D supplementation didn't further increase the plasma concentrations (Tsang and Grunder, 1993). At the beginning of the present study, vitamin D was supplemented routinely at both facilities. Ceasing this supplementation would therefore expect to decrease the values of the vitamin D metabolites. Nevertheless, values of $1,25-(\mathrm{OH})_{2}-\mathrm{D}$ at both facilities were not influenced significantly, and a decrease in 25-OH-D and subsequent fall in tCa could only be observed at facility 2. As vitamin D is fat-soluble, it can be stored in the fat tissue and be mobilized slowly (Stanford, 2006b). Penguins with higher body fat portion might have a higher vitamin D storage capacity. The blubber in free-living Adélie penguins pre-moulting or arriving for breeding was 10 to $17 \mathrm{~mm}$ thick (Johnson and West, 1973; Markert and Sladen, 1966). In marine mammals, higher vitamin D contents in the blubber were found in primarily piscivorous species such as the ringed seals (Phoca hispida) compared to species feeding on invertebrates such as the bowhead whale (Balaena mysticetus; Kenny et al., 2004). This storage capacity could also lead to a resistance to vitamin D intoxication in animals naturally feeding on a diet rich in vitamin D, as hypothesised in hooded seals (Cystophora cristata; Keiver et al., 1988). Studies in hens showed that it takes 2 to 7 weeks to deplete body vitamin D stores and become dependent on the dietary vitamin D content (Atencio et al., 2005; National Research Council USA, 1987; Tsang and Grunder, 1993). It is therefore questionable if four weeks without 
supplementation in this study were long enough to deplete the body stores in gentoo penguins. It can be hypothesized, that 25-OH-D plasma concentrations of the study period (D) at facility 2 were above the physiological range and therefore decreased after the reduction of the dietary vitamin D intake from 3454 IU/animal to 2454 IU/animal, whereas at facility 1 the plasma concentrations remained nearly constant through the use of vitamin D storages in fat tissues.

The provision of UV-light in this study did not have any significant influence on the measured vitamin $\mathrm{D}$ metabolites at both facilities, even though birds are able to synthesize vitamin $\mathrm{D}_{3}$ in an endogenous, UVB-light dependent reaction. Two explanations are likely: 1) the UVB irradiances were not sufficient for vitamin D photoconversion, or 2) the vitamin D requirements were already satisfied through the diet. In budgerigars, a threshold dose of $113-225 \mathrm{~mJ} / \mathrm{cm}^{2}$ was determined (Lupu and Robins, 2013). No specific information exists about the ability of endogenous vitamin $\mathrm{D}_{3}$ synthesis and required UVB threshold dose for penguins. The dense feathers as an adaptation to the cold weather conditions and the low average UVB radiation in their natural habitat (Beckmann et al., 2014) might lead to a low dependency on endogenous vitamin $\mathrm{D}_{3}$ production. In free-living Adélie and chinstrap ( $P$. antarctica) penguins no significant increase in 25-OH-D concentrations due to the longer exposure to sunlight during the nesting season was observed (Griffiths and Fairney, 1988). It is hypothesised that some marine species rely in nature mainly on vitamin D ingestion (Kenny et al., 2004). Nevertheless, at facility 1, plasma concentrations of 25-OH-D increased continuously from the study period (Baseline) to the study periods (D) and (UVB), with intra- individual differences of $6(-8-18)$ $\mathrm{nmol} / \mathrm{l}$ and $10(-11-58) \mathrm{nmol} / \mathrm{l}$, respectively, presuming that gentoo penguins are able to endogenously synthesis vitamin D and the UVB dose was sufficient for this reaction. In contrast, 25-OH-D increased only slightly with the provision of UV-light at facility 2, remaining well below the values of the study period (D). These findings further support the assumption that 25-OH-D concentrations of the study period (D) at facility 2 were higher than the physiological values. The provision of UV-light increased values of $\mathrm{tCa}$ at facility 2 , and of $\mathrm{iCa}$ and tCa but only for females at facility 1 . The latter might also have been influenced by the beginning of the nesting season. Contact to direct sunlight or the provision of UV-light increased $\mathrm{iCa}$ concentrations also in other bird species such as Humboldt penguins (Adkesson and Langan, 2007), African spoonbills (Platalea alba; Woodhouse and Rick, 2016) or African grey parrots (Stanford, 2006b). In the latter, tCa also increased significantly as 25-OH-D did, but only if fed a diet containing no vitamin $\mathrm{D}$, whereas no increase was observed if fed a diet containing $1650 \mathrm{IU} \mathrm{D} / \mathrm{kg}$. 
During the last experimental period (UVB), at facility 1, two females (33128 and 34421) showed behaviour that could be related to eggs layed 29 and 40 days later, respectively. They also showed high tCa values, which raises the question if these values were due to the provision of UV-light or mainly due to the onset of the breeding season.

\section{Conclusion}

The findings in this study showed that special care should be taken when supplementing piscivorous animals with vitamin $\mathrm{D}$, as its contents in feeding-fishes can vary considerably. Even though sample size was low and time of study short, a requirement of dietary vitamin D for gentoo penguins kept indoors between 1130 IU and 3454 IU per animal and day is likely. The vitamin D content of the diet also influenced the impact of the provision of UV-light. Gentoo penguins might not relay on endogenous vitamin D synthesis and therefore UVB radiation, if the fish diet contains enough vitamin D. A constant radiation dose of $194 \mathrm{~mJ} / \mathrm{cm}^{2}$ over a period of two weeks was safe.

\section{Acknowledgments}

We thank the Zoo Wuppertal and Maya Kummrow for supporting this study by securing the experimental animal licence, performing the feeding and UVB trials, and by taking the blood samples. We also thank the staff at both zoological institutions for their great support throughout the project, the commissaries of animal welfare at both institutions for their help during the planning of the study, and Ines Mittner for her support in laboratory issues. The study was financially supported by Sea Life Konstanz and the Swiss Association for Wildlife, Zoo and Exotic Pets. The sponsoring of EG7+ cartridges for the iSTAT at facility 1 by Axon Lab AG, Baden, Switzerland is very much appreciated.

\section{References}

Adkesson, M.J.; Langan, J.N., 2007: Metabolic bone disease in juvenile Humboldt penguins (Spheniscus humboldti): investigation of ionized calcium, parathyroid hormone, and vitamin $\mathrm{D}_{3}$ as diagnostic parameters. Journal of Zoo and Wildlife Medicine 38, 85-92. doi: 10.1638/06-004.1.

Atencio, A.; Edwards, H.M., JR; Pesti, G.M.; Ware, G.O., 2006: The vitamin $\mathrm{D}_{3}$ requirement of broiler breeders. Poultry Science 85, 674-692. 
Atencio, A.; Pesti, G.M.; Edwards, H.M., JR, 2005: Twenty-five hydroxycholecalciferol as a cholecalciferol substitute in broiler breeder hen diets and its effect on the performance and general health of the progeny. Poultry Science 84, 1277-1285.

Beckmann, M.; Václavík, T.; Manceur, A.M.; Šprtová, L.; Wehrden, H. von; Welk, E.; Cord, A.F., 2014: glUV: a global UV-B radiation data set for macroecological studies. Methods in Ecology and Evolution 5, 372-383. doi: 10.1111/2041-210X.12168.

Bernard, J.B., 1997: Feeding captive piscivorous animals: nutritional aspects of fish as food. In: AZA Nutrition Advisory Group Handbook Fact Sheet 005.

Clausen, A.P.; Pütz, K., 2002: Recent trends in diet composition and productivity of gentoo, magellanic and rockhopper penguins in the Falkland Islands. Aquatic Conservation: Marine and Freshwater Ecosystems 12, 51-61. doi: 10.1002/aqc.476.

Clausen, A.; Pütz, K., 2003: Winter diet and foraging range of gentoo penguins (Pygoscelis papua) from Kidney Cove, Falkland Islands. Polar Biology 26, 32-40. doi: 10.1007/s00300002-0443-2.

Council of the European Union, 1970: Council Directive of 23 November 1970 concerning additives in feeding-stuffs (70/524/EEC). Official Journal of the European Communities $\mathbf{L}$ 270, 1-17.

Cousquer, G.O.; Dankoski, E.J.; Patterson-Kane, J.C., 2007: Metabolic bone disease in wild collared doves (Streptopelia decaocto). The Veterinary Record 160, 78-84.

Crissey, S.; Slifka, K.; McGill, P., 2005: Diet and Nutrition. In: AZA Penguin Taxon Advisory Group, Penguin Husbandry Manual, 3rd edn, American Zoo and Aquarium Association, Silver Spring, MD 20910-3314, pp. 65-85.

Deutsches Institut für Normung (DIN), 2009: Foodstuffs - Determination of vitamin D by high performance liquid chromatography - Measurement of cholecalciferol (D3) or ergocalciferol (D2); German version EN 12821:2009. Beuth Verlag, Berlin.

Dobreva, D.A.; Merdzhanova, A.; Stancheva, M., 2013: Effect of frozen storage on fat soluble vitamins content in fish fillets. Scripta Scientifica Medica 45, 14-17.

Garcia, A.F.Q.M.; Murakami, A.E.; Duarte, C.R.A.; Rojas, I.C.O.; Picoli, K.P.; Puzotti, M.M., 2013: Use of vitamin D3 and its metabolites in broiler chicken feed on performance, bone parameters and meat quality. Asian-Australasian Journal of Animal Sciences 26, 408-415. doi: 10.5713/ajas.2012.12455.

Ghebremeskel, K.; Williams, G.; Keymer, I.F.; Horsley, D.; Gardner, D.A., 1989: Plasma chemistry of rockhopper (Eudyptes crestatus), magellanic (Spheniscus magellanicus) and gentoo (Pygoscelis papua) wild penguins in relation to moult. Comparative Biochemistry and Physiology Part A: Physiology 92, 43-47. doi: 10.1016/0300-9629(89)90738-X.

Griffiths, P.; Fairney, A., 1988: Vitamin D metabolism in polar vertebrates. Comparative Biochemistry and Physiology. B: Comparative Biochemistry 91, 511-516. doi: 10.1016/03050491(88)90014-4.

Howard, L.L.; Kass, P.H.; Lamberski, N.; Wack, R.F., 2004: Serum concentrations of ionized calcium, vitamin D3, and parathyroid hormone in captive thick-billed parrots (Rhynchopsitta pachyrhyncha). Journal of Zoo and Wildlife Medicine 35, 147-153. doi: 10.1638/03-062.

Hymoller, L.; Jensen, S.K., 2011: Vitamin D analysis in plasma by high performance liquid chromatography (HPLC) with $\mathrm{C}(30)$ reversed phase column and UV detection - easy and acetonitrile-free. Journal of Chromatography. $A$ 1218, 1835-1841. doi: 10.1016/j.chroma.2011.02.004. 
Jiang, S.; Jiang, Z.; Yang, K.; Chen, F.; Zheng, C.; Wang, L., 2015: Dietary vitamin D3 requirement of Chinese yellow-feathered broilers. Poultry Science 94, 2210-2220. doi: $10.3382 / \mathrm{ps} / \mathrm{pev} 163$.

Johnson, S.R.; West, G.C., 1973: Fat content, fatty acid composition and estimates of energy metabolism of Adélie penguins (Pygoscelis adeliae) during the early breeding season fast. Comparative Biochemistry and Physiology Part B: Comparative Biochemistry 45, 709-719.

Keiver, K.M.; Draper, H.H.; Ronald, K., 1988: Vitamin D metabolism in the hooded seal (Cystophora cristata). The Journal of Nutrition 118, 332-341.

Kenny, D.E.; O'Hara, T.M.; Chen, T.C.; Lu, Z.; Tian, X.; Holick, M.F., 2004: Vitamin D content in Alaskan Arctic zooplankton, fishes, and marine mammals. Zoo Biology 23, 33-43. doi: 10.1002/zoo.10104.

Lietzow, J.; Kluge, H.; Brandsch, C.; Seeburg, N.; Hirche, F.; Glomb, M.; Stangl, G.I., 2012: Effect of short-term UVB exposure on vitamin D concentration of eggs and vitamin D status of laying hens. Journal of Agricultural and Food Chemistry 60, 799-804. doi: 10.1021/jf204273n.

Lumeij, J.T., 1994: Endocrinology. Calcium Metabolism. In: Ritchie, B.W.; Harrison, G.J.; Harrison, L.R. (eds.), Avian Medicine: Principles and Application (pp. 587-593). Wingers Publishing, Lake Worth, U.S. Endocrinology.

Lupu, C.; Robins, S., 2013: Determination of a safe and effective ultraviolet B radiant dose in budgerigars (Melopsittacus undulatus): a pilot study. Journal of Avian Medicine and Surgery 27, 269-279. doi: 10.1647/2011-0291.

Markert, C.L.; Sladen, W.J.L., 1966: Stability of lactate dehydrogenase isozyme patterns in penguins. Nature 210, 948-949.

Mattila, P.; Ronkainen, R.; Lehikoinen, K.; Piironen, V., 1999: Effect of household cooking on the vitamin D content in fish, eggs, and wild mushrooms. Journal of food composition and analysis 12, 153-160. doi: 10.1006/jfca.1999.0828

Matos, R. de, 2008: Calcium metabolism in birds. The Veterinary Clinics of North America. Exotic Animal Practice 11, 59-82. doi: 10.1016/j.cvex.2007.09.005.

Nain, S.; Laarveld, B.; Wojnarowicz, C.; Olkowski, A.A., 2007: Excessive dietary vitamin D supplementation as a risk factor for sudden death syndrome in fast growing commercial broilers. Comparative Biochemistry and Physiology. Part A: Molecular \& Integrative Physiology 148, 828-833. doi: 10.1016/j.cbpa.2007.08.023.

National Research Council USA, 1987: Vitamin Tolerance of Animals. The National Academies Press, Washington, DC.

Olds, J.E.; Burrough, E.; Madison, D.; Ensley, S.; Horst, R.; Janke, B.H.; Schwartz, K.; Stevenson, G.W.; Gauger, P.; Cooper, V.L.; Arruda, P.; Opriessnig, T., 2015: Clinical investigation into feed-related hypervitaminosis $\mathrm{D}$ in a captive flock of budgerigars (Melopsittacus undulatus): morbidity, mortalities, and pathologic lesions. Journal of Zoo and Wildlife Medicine 46, 9-17. doi: 10.1638/2013-0062R2.1.

Pinheiro, J.; Bates, D.; DebRoy, S.; Sarkar, D.; R Core Team, 2016: nlme: Linear and Nonlinear Mixed Effects Models. $R$ package Version 3.1-127, http://CRAN.Rproject.org/package $=$ nlme.

$\mathrm{R}$ Core Team, 2016: $R$ : A language and environment for statistical computing. R Foundation for Statistical Computing, Vienna, Austria. https://www.R-project.org/.

Sahari, M.A.; Ahmadnia, A.; Barzegar, M.; Noorolahi, Z., 2014: Vitamin losses during frozen storage of Liza aurata (Risso, 1810), Cyprinus carpio L. 1758, Clupeonella cultriventris 
caspia (Nordmann, 1840), Rutilus frisii kutum (Kamenskii, 1901) and Sander lucioperca (L., 1758). Journal of Applied Ichthyology 30, 366-371. doi: 10.1111/jai.12388.

Schaftenaar, W.; van Leeuwen, J.P., 2015: The influence of ultraviolet-B radiation on the growth of Marabou stork (Leptoptilos crumeniferus) nestlings in relation to plasma calcium, phosphorus, and vitamin D3 concentrations. Journal of Zoo and Wildlife Medicine 46, 682690. doi: 10.1638/2014-0031.1.

Sedrani, S.H., 1984: Changes in serum levels of 1,25-dihydroxyvitamin D3, calcium and phosphorus with age and vitamin D status in chickens. British Journal of Nutrition 52, 329 334. doi: 10.1079/BJN19840099.

Shojadoost, B.; Behboudi, S.; Villanueva, A.I.; Brisbin, J.T.; Ashkar, A.A.; Sharif, S., 2015: Vitamin D3 modulates the function of chicken macrophages. Research in Veterinary Science 100, 45-51. doi: 10.1016/j.rvsc.2015.03.009.

Stancheva, M.; Merdzhanova, A.; Dobreva, D.A.; Makedonski, L., 2010: Fatty acid composition and fat-soluble vitamins content of sprat (Sprattus sprattus) and goby (Neogobius rattan) from Bulgarian Black Sea. Ovidius University Annals of Chemistry 21, 23-28.

Stanford, M., 2003: Measurement of 25-hydroxycholecalciferol in captive grey parrots (Psittacus e erithacus). The Veterinary Record 153, 58-59.

Stanford, M., 2006a: Calcium Metabolism. In: Harrison, G.; Lightfoot, T. (eds.), Clinical Avian Medicine, Vol. 1 (pp. 141-152). Brenthwood, TN: Avian Medicine Online by Harrison's Bird Foods. Clinical Avian Medicine.

Stanford, M., 2006b: Effects of UVB radiation on calcium metabolism in psittacine birds. The Veterinary Record 159, 236-241.

Stanford, M., 2007: Clinical pathology of hypocalcaemia in adult grey parrots (Psittacus e erithacus). The Veterinary Record 161, 456-457.

Steinmetz, H.W.; Vogt, R.; Kastner, S.; Riond, B.; Hatt, J.M., 2007: Evaluation of the i-STAT portable clinical analyzer in chickens (Gallus gallus). Journal of Veterinary Diagnostic Investigation 19, 382-388. doi: 10.1177/104063870701900407.

Suzuki, H.; Hayakawa, S.; Wada, S.; Okazaki, E.; Yamazawa, M., 1988: Effect of solar drying on vitamin D3 and provitamin D3 contents in fish meat. Journal of Agricultural and Food Chemistry 36, 803-806. doi: 10.1021/jf00082a033.

Tangredi, B.P.; Krook, L.P., 1999: Nutritional secondary hyperparathyroidism in free-living fledgling American crows (Corvus brachyrhynchos brachyrhynchos). Journal of Zoo and Wildlife Medicine 30, 94-99.

Teare, J.A. (ed.), 2013: Gentoo penguin (Pygoscelis papua): Standard International Units. In: ISIS Physiological Reference Intervals for Captive Wildlife: A CD-ROM Resource. International Species Information System. Bloomington, MN.

Tsang, C.P.W.; Grunder, A.A., 1993: Effect of dietary contents of cholecalciferol, 1 $\alpha, 25-$ dihydroxycholecalciferol and 24,25-dihydroxycholecalciferol on blood concentrations of 25hydroxycholecalciferol, 1 $\alpha, 25$-dihydroxycholecalciferol, total calcium and eggshell quality. British Poultry Science 34, 1021-1027. doi: 10.1080/00071669308417661.

Woodhouse, S.J.; Rick, M., 2016: The effect of UVB radiation on serum vitamin D and ionized calcium in the African spoonbill (Platalea alba). Journal of Zoo and Wildlife Medicine 47, 447-456. doi: 10.1638/2014-0239.1.

Worthy, G.A.J., 2001: Nutrition and Energetics. In: Dierauf, L.A.; Gulland, F.M.D. (Eds.) CRC Handbook of Marine Mammal Medicine. CRC Press, 791-827. doi: 10.1201/9781420041637.ch36. 


\section{Danksagung}

An dieser Stelle möchte ich mich ganz herzlich bei meinen Co-Autoren Annette Liesegang, Hanspeter Steinmetz und Simon Rüegg, sowie bei Maya Kummrow für ihr Engagement und ihre Unterstützung bei der Planung und Durchführung der Studie und/oder Erarbeitung des Papers bedanken. Ein ganz besonderer Dank geht an Annette Liesegang für ihre Hilfe beim Abschluss des Papers. 


\section{Curriculum vitae}

$\begin{array}{ll}\text { Vorname Name } & \text { Ursina Tröndle } \\ \text { Geburtsdatum } & 30.09 .1976 \\ \text { Geburtsort } & \text { Samedan } \\ \text { Nationalität } & \text { CH } \\ \text { Heimatort bei Schweizern } & \text { Zürich } \\ \text { Aug 1989 - Jun 1996 } & \text { Kantonsschule Obwalden, Sarnen, Schweiz } \\ \text { Jun 1996 } & \begin{array}{l}\text { Matura (Typus B Latein), Kantonsschule Obwalden, Sarnen, } \\ \text { Schweiz }\end{array} \\ \text { Sept } 1996-\text { Dez 2001 } & \begin{array}{l}\text { Studium Veterinärmedizin, Tierspital (Vetsuisse Fakultät), } \\ \text { Universität Bern, Bern, Schweiz }\end{array} \\ \text { Dez 2001 } & \text { Diplom eidg. Tierärztin, Universität Bern, Bern, Schweiz } \\ \text { Okt 2002 - Sept 2003 } & \begin{array}{l}\text { Masterkurs in Wild Animal Health, Royal Veterinary } \\ \text { College, London, England }\end{array} \\ \text { Sept 2003 } & \begin{array}{l}\text { Master of Science in Wild Animal Health, Royal Veterinary } \\ \text { College, London, England }\end{array}\end{array}$

Aug 2013 - Mai 2018 Anfertigung der Dissertation

unter Leitung von Prof Dr. med. vet Annette Liesegang

am Institut für Tierernährung

der Vetsuisse-Fakultät Universität Zürich

Direktorin Prof. Dr. med. vet. Annette Liesegang
Mai 2002 - Sept 2002 Assistenztierärztin in der Tierarztpraxis H. Lauener
(Grosstiere), Frutigen, Schweiz
Jan 2004 - Okt 2007 Assistenztierärztin in der Tierarztpraxis B. Disler
(Gemischtpraxis), Kleindietwil, Schweiz
Mai $2008-$ Okt 2008 Assistenztierärztin in der Tierklinik am Kreis
(Gemischtpraxis), Netstal, Schweiz
Dez 2008 - Feb 2014 Assistenztierärztin in der Tierklinik Nesslau (Kleintiere),
Nesslau, Schweiz
März 2014 - Feb 2015 Assistenztierärztin in der Solovet Tierärzte AG (Kleintiere), Egerkingen, Schweiz
Mai $2015 \quad-$ heute Assistenztierärztin in der Tierarztpraxis Salm (Schwerpunkt Kleintiere), Langenthal, Schweiz

